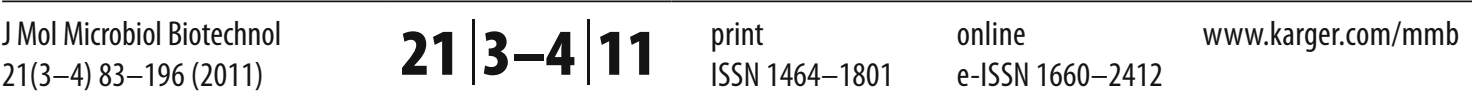

\title{
Jourinal of
}
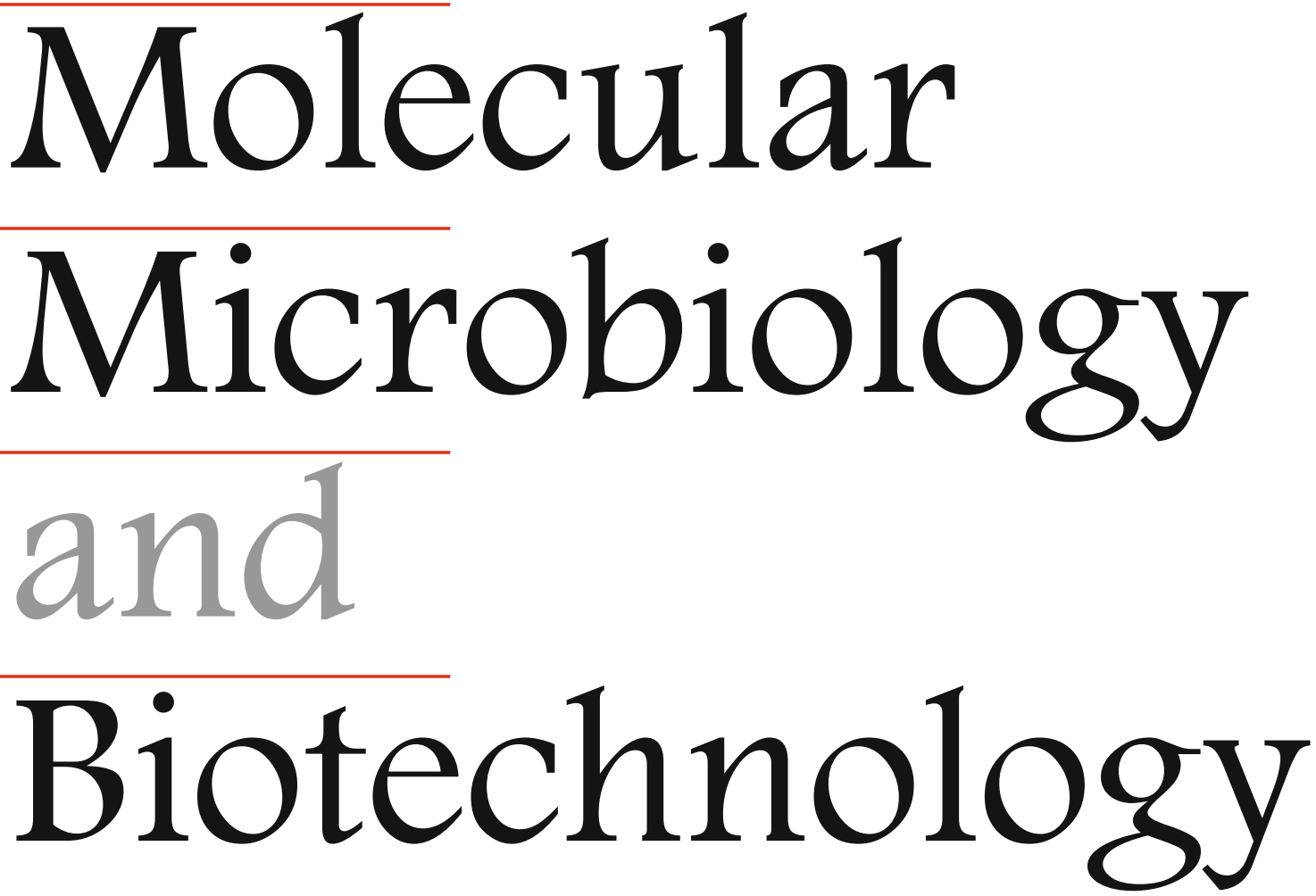

S. Karger
Medical and Scientific Publishers Basel · Freiburg · Paris .

London - New York · New Delhi .

Bangkok · Beijing · Tokyo ·

Kuala Lumpur - Singapore . 


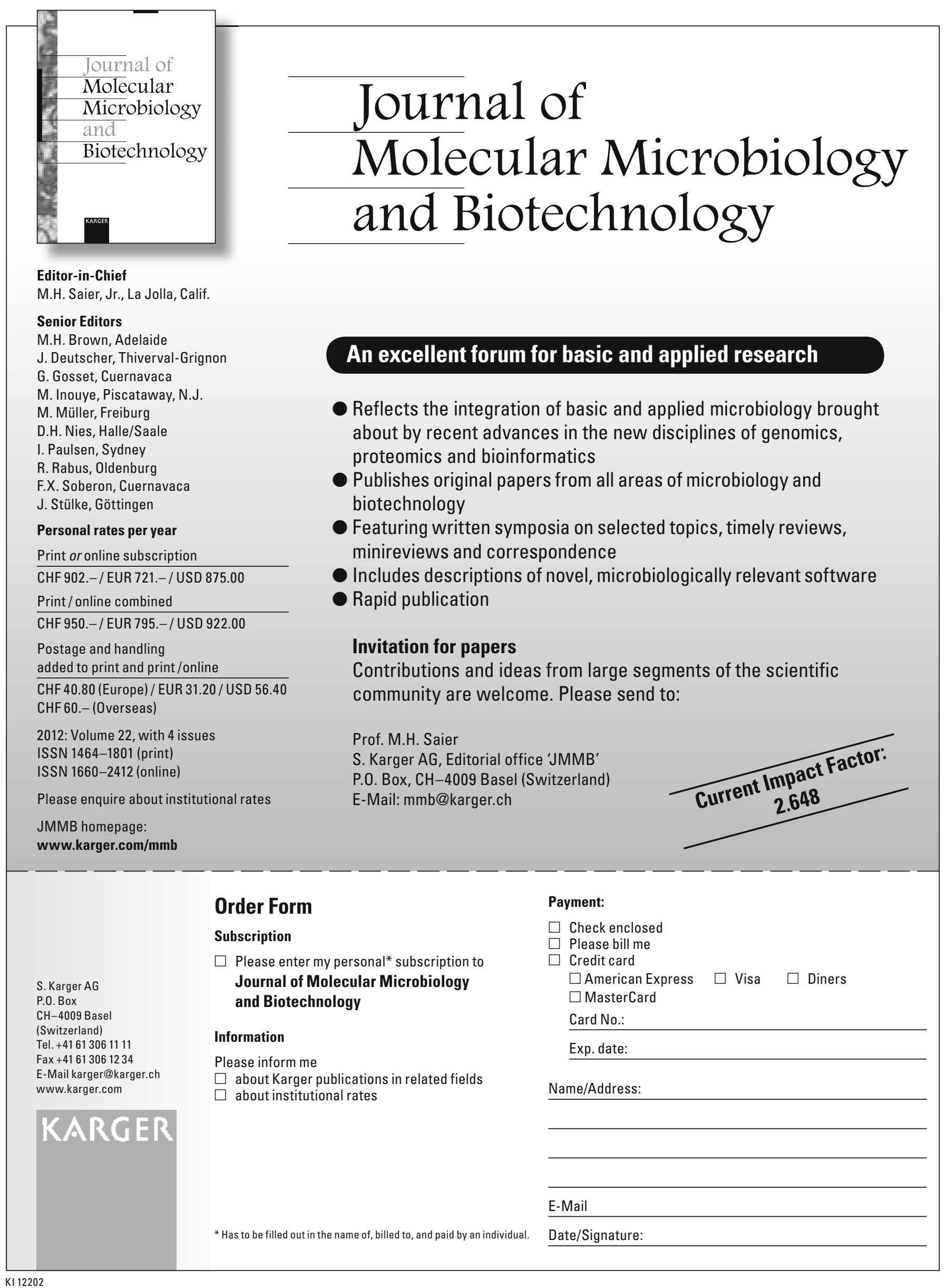

KI 12202 


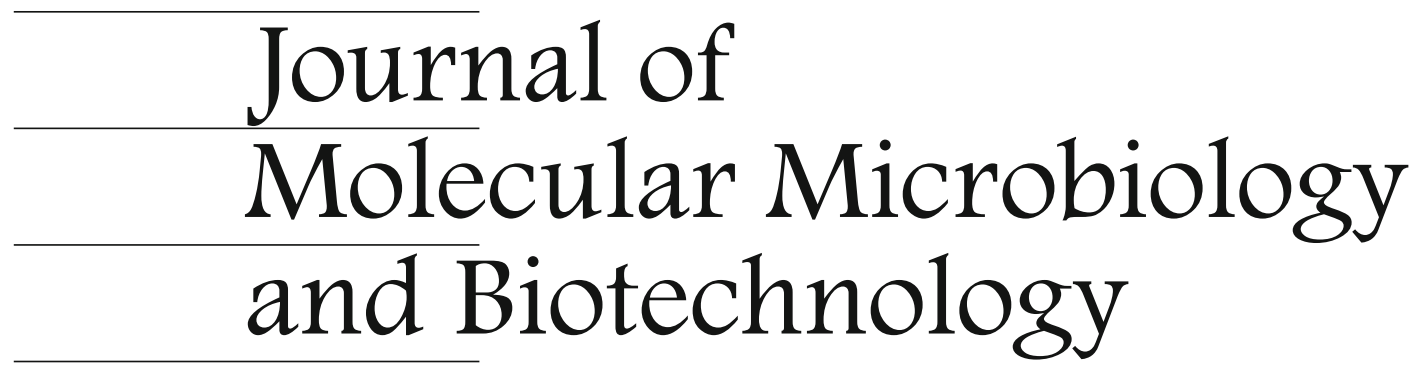

\section{Editor-in-Chief}

M.H. Saier, Jr., La Jolla, Calif.

\section{Senior Editors}

M.H. Brown, Adelaide

J. Deutscher, Thiverval-Grignon

G. Gosset, Cuernavaca

M. Inouye, Piscataway, N.J.

M. Müller, Freiburg

D.H. Nies, Halle/Saale

I. Paulsen, Sydney

R. Rabus, Oldenburg

F.X. Soberon, Cuernavaca

J. Stülke, Göttingen

\section{Editorial Board}

F. Barras, Marseille

D.H. Bartlett, San Diego, Calif.

P. Beguin, Paris

I. Booth, Aberdeen

L.J. Brady, Gainesville, Fla.

Y.J. Chung, Jeonju

P. Courvalin, Paris

C.J. Dorman, Dublin

J.S. Edwards, Albuquerque, N. Mex.

M.Y. Galperin, Bethesda, Md.

A. Goffeau, Louvain-la-Neuve

C.F. Gonzalez, Gainesville, Fla.

M. Gribskov, West Lafayette, Ind.

G.F. Hatfull, Pittsburgh, Pa.
P.J.F. Henderson, Leeds

S. Horinouchi, Tokyo

G. Klug, Giessen

G.L. Lorca, Gainesville, Fla.

J. Lutkenhaus, Kansas City, Kans.

W. Qin, Thunder Bay, Ont.

M. Schaechter, San Diego, Calif.

K.C. Schuster, Lenzing

R. Skurray, Sydney

F. Titgemeyer, Münster

R. Vazquez-Duhalt, Cuernavaca

H. Wolf-Watz, Umea

X. Zhou, Pullman, Wash. 
Journal of Molecular Microbiology and Biotechnology

\section{Aims and Scope}

The 'Journal of Molecular Microbiology and Biotechnology' (JMMB) publishes high-quality primary and original research papers in all areas of molecular microbiology and molecular biotechnology. It also features written symposia on unified topics, timely reviews, minireviews, and a section devoted to correspondence and comments. 'JMMB' provides a medium for the amalgamation of the disciplines of molecular microbiology and biotechnology in the genomics era. 'JMMB' encourages the submission of all manuscripts relating to the molecular biology or molecular biotechnology of bacteria, viruses, and eukaryotic microorganisms.

\section{Submission}

Manuscripts should be submitted online at: www.karger.com/mmb

where you will also find a link to the Submission Website. Names, postal and e-mail addresses of four experts in the appropriate area of research should accompany each manuscript. Selected scientist(s) will be invited to act as referee(s). Referees suggested should not be from the same institution as the author and should have expert knowledge of the subject. Should you experience problems with your submission, please contact:

mmb@karger.ch
S. Karger AG
Editorial Office 'Journal of Molecular
Microbiology and Biotechnology'
P.O. Box
CH-4009 Basel (Switzerland)
Tel. +41 613061344
Fax +41613061434

\section{Conditions}

All manuscripts are subject to editorial review. Manuscripts are received with the explicit understanding that they are not under simultaneous consideration by any other publication. A covering letter should be included with both the first and final version of the manuscript with the signature of all authors to confirm that they have seen and approved the submission. Submission of an article for publication implies the transfer of the copyright from the author to the publisher upon acceptance. Accepted papers become the permanent property of 'Journal of Molecular Microbiology and Biotechnology' and may not be reproduced by any means, in whole or in part, without the written consent of the publisher. It is the author's responsibility to obtain permission to reproduce illustrations, tables, etc. from other publications. It is a policy of the journal that nucleotide sequence data should be deposited with the EMBL/GenBank/DDBJ libraries prior to publication, and the accession number should be quoted in the manuscript.

\section{Arrangement}

English: All manuscripts must be written in perfect English. Before you submit, please ensure that your manuscript is corrected by someone who speaks English as his or her first language.

Title page: The first page of each paper should indicate the title, the authors' names, the institute where the work was conducted, and a short title for use as running head.

Full address: The exact postal address of the corresponding author complete with postal code must be given at the bottom of the title page. Please also supply phone and fax numbers, as well as e-mail address.

Key words: Please supply 3-10 key words in English that reflect the content of the paper.

Abstract: Each paper must include an abstract. Abstracts should be 100-200 words.

Running Title: Each paper must include a running title of no more than 80 characters.

Research Articles: Original research articles should be sub-divided into the following sections:

- Abstract

- Introduction (concise with no sub-headings)

- Results (may be sub-divided)

- Discussion (results and discussion may be combined and may include sub-headings)

- Experimental Procedures

(should be sufficiently detailed to permit the experiments to be reproduced)

- Acknowledgements

- References

Reviews: Review articles should be sub-divided into the following sections:

- Abstract

- Introduction (concise with no sub-headings)

- The main text of the paper

(should be divided under various headings as appropriate to the article)

- Acknowledgements

- References

Communications: Short Communications should be 2-5 journal pages in length, should include an abstract and running title, but should not be divided into introduction, results, discussion, and experimental procedures sections. Sub-sections specifying topic are permissible.

Units: Concentration to be given in $\mathrm{g} / \mathrm{l}$, etc., or molarity, $\mathrm{M}$. Use the format $\mu \mathrm{g} / \mathrm{ml}$ not $\mu \mathrm{g} \mathrm{ml}-1$. Note $\mathrm{ml}$ not $\mathrm{mL}$.

Footnotes: Avoid footnotes. When essential, they are numbered consecutively and typed at the foot of the appropriate page.
Tables and Illustrations: Tables and illustrations (both numbered in Arabic numerals) should be prepared on separate sheets. Tables require a heading and figures a legend, also prepared on a separate sheet. For the reproduction of illustrations, only good drawings and original photographs can be accepted; negatives or photocopies cannot be used. Due to technical reasons, figures with a screen background should not be submitted. When possible, group several illustrations on one block for reproduction (max. size $180 \times 223 \mathrm{~mm}$ ) or provide crop marks. $\mathrm{B} / \mathrm{w}$ half-tone and color illustrations must have a final resolution of $300 \mathrm{dpi}$ after scaling, line drawings one of 800-1200 dpi.

\section{Color Illustrations}

Online edition: Color illustrations are reproduced free of charge. In the print version, the illustrations are reproduced in black and white. Please avoid referring to the colors in the text and figure legends. Print edition: Up to 6 color illustrations per page can be integrated within the text at CHF 800.- per page.

References: Identify references [in square brackets] in the text by naming the authors and the year. 1 author: [Saier, 1994]; 2 authors: [Altschul and Karlin, 1990]; 3 and more authors: [Yen et al., 2002]. Several references listed within square brackets should be cited in an alphabetical order. Material submitted for publication but not yet accepted should be noted as 'unpublished data' and may not be included in the reference list. The list of references should include only those publications cited in the text. Arrange the reference list in strict alphabetical order according to the examples given below. The authors' surnames followed by their initials should be given, and each name should be separated by a comma. Preferably, please cite all authors. For papers by the same authors, listing should be according to the year; for papers by the same authors published in the same year, use the letters a, b, c, etc. directly (no space) connected to the year. For journal abbreviations, please use the Index Medicus system.

\section{Examples}

(a) Papers published in periodicals: Andrade MA, Ponting C, Gibson T, Bork P: Homology-based method for identification of protein repeats using statistical significance estimates. J Mol Biol 2000;298:521-537.

(b) Papers published only with DOI numbers:

Theoharides TC, Boucher W, Spear K: Serum interleukin-6 reflects disease severity and osteoporosis in mastocytosis patients. Int Arch Allergy Immunol DOI: $10.1159 / 000063858$.

(c) Monographs: Matthews DE, Farewell VT: Using and Understanding Medical Statistics. Basel, Karger, 1985 .

(d) Edited books: Russell RRB: Genetic analysis and genetic probes for oral bacteria; in Ferguson DB (ed): Aspects of Oral Molecular Biology. Front Oral Physiol. Basel, Karger, 1991, vol 8, pp 57-76.

\section{KARGER}

Fax +4161306 1234 E-Mail karger@karger.ch www.karger.com (c) 2012 S. Karger AG, Basel 


\section{Digital Object Identifier (DOI)}

S. Karger Publishers supports DOIs as unique identifiers for articles. A DOI number will be printed on the title page of each article. DOIs can be useful in the future for identifying and citing articles published online without volume or issue information. More information can be found at www.doi.org.

\section{Supplementary Material}

Supplementary material is restricted to additional data that are not necessary for the scientific integrity and conclusions of the paper. Please note that all supplementary files will undergo editorial review and should be submitted together with the original manuscript. The Editors reserve the right to limit the scope and length of the supplementary material. Supplementary material must meet production quality standards for Web publication without the need for any modification or editing. In general, supplementary files should not exceed $10 \mathrm{MB}$ in size. All figures and tables should have titles and legends and all files should be supplied separately and named clearly. Acceptable files and formats are: Word or PDF files, Excel spreadsheets (only if the data cannot be converted properly to a PDF file), and video files (.mov, .avi, .mpeg)

\section{Author's Choice ${ }^{\mathrm{TM}}$}

Karger's Author's Choice ${ }^{\mathrm{TM}}$ service broadens the reach of your article and gives all users worldwide free and full access for reading, downloading and printing at www.karger.com. The option is available for a one-time fee of CHF 3000.-, which is a permissible cost in grant allocation. More information can be found at www.karger.com/authors_choice.

\section{NIH-Funded Research}

The U.S. National Institutes of Health (NIH) mandates under the NIH Public Access Policy that final, peer-reviewed manuscripts appear in its digital database within 12 months of the official publication date. As a service to authors, Karger submits the final version of your article on your behalf to PubMed Central. For those selecting our premium Author's Choice ${ }^{\mathrm{TM}}$ service, we will send your article immediately upon publishing, accelerating the accessibility of your work without the usual embargo. More details on NIH's Public Access Policy is available at http://publicaccess.nih.gov/policy.htm

\section{Self-Archiving}

Karger permits authors to archive their pre-prints (i.e. pre-refereeing) or post-prints (i.e. final draft post-refereeing) on their personal or institution's servers, provided the following conditions are met: Articles may not be used for commercial purposes, must be linked to the publisher's version, and must acknowledge the publisher's copyright. Authors selecting Karger's Author's Choice ${ }^{\mathrm{TM}}$ feature, however, are also permitted to archive the final, published version of their article, which includes copyediting and design improvements as well as citation links.

\section{Page Charges}

There are no page charges for papers of 6 or fewer printed pages (including tables, illustrations and references). A charge of CHF 325.- will be levied for all pages in excess of the allotted 6 printed pages. The allotted size of a paper is equal to approx. 18 manuscript pages (including tables, illustrations and references)

\section{Proofs}

Unless indicated otherwise, proofs are sent to the corresponding author and should be returned with the least possible delay. Alterations other than the correction of printer's errors are charged to the author.

\section{Reprints}

The corresponding authors of all papers will receive a one-year online subscription to 'JMMB' free of charge. Order forms and a price list for additional reprints are sent with the galley proof. Orders submitted after the issue is printed are subject to considerably higher prices.

\section{'A collection of extraordinary essays'}

\section{GOTTFRIED SCHATZ}

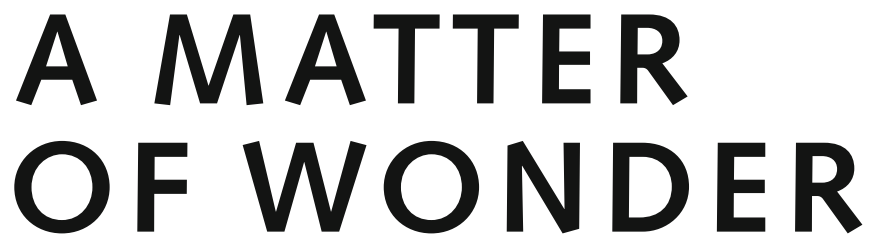

\section{What Biology Reveals about Us, Our World, and Our Dreams}

Where do we come from? Is our destiny determined by the genes we inherit? In this book Gottfried Schatz, the world-renowned biochemist and co-discoverer of mitochondrial DNA, gives lucid - albeit often surprising - answers to universal questions and takes the reader on a fascinating journey of discovery across the boundaries of scientific disciplines. With passion and a keen sense of wonder he draws on philosophy, cultural history and art to formulate his reflections on the mysteries of life. His essays will appeal not only to scientists but to all inquisitive minds, regardless of educational and professional background.

\section{KARGER}

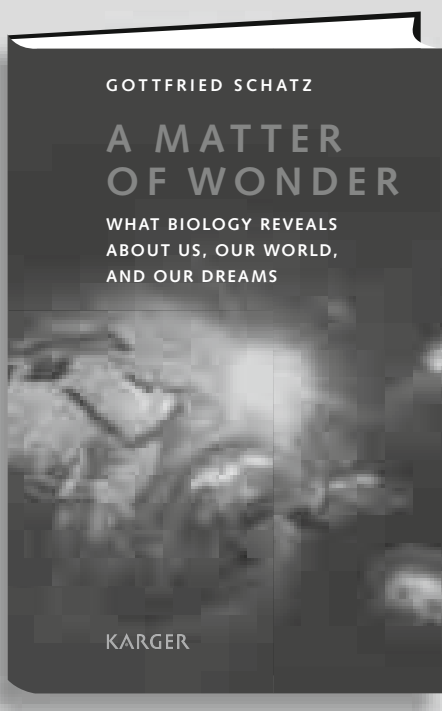

G. Schatz (Basel)

A Matter of Wonder

What Biology Reveals about Us, Our World, and Our Dreams

Translated by A. Shields

XII + 190 p., 2 color fig., hard cover, 2011

CHF 29.- / EUR 21.50/USD 29.00

ISBN 978-3-8055-9744-9

More information and sample essays at www.karger.com/schatz

\section{KARGER}

Fax +4161306 1234

E-Mail karger@karger.ch

www.karger.com
(C) 2012 S. Karger AG, Basel

The Guidelines for Authors are available at:

www.karger.com/mmb_Guidelines 
Journal of Molecular Microbiology and Biotechnology

ISSN Print Edition: 1464-1801

ISSN Online Edition: 1660-2412

Journal Homepage: www.karger.com/mmb

Publication Data: 'Journal of Molecular Microbiology and Biotechnology' is published 8 times a year. Volumes 20 and 21 with 4 issues each appear in 2011.

Copyright: (C) 2011 S. Karger AG, Basel (Switzerland). All rights reserved. No part of this publication may be translated into other languages, reproduced or utilized in any form or by any means, electronic or mechanical, including photocopying, recording, microcopying, or by any information storage and retrieval system, without permission in writing from the publisher or, in the case of photocopying, direct payment of a specified fee to the Copyright Clearance Center.

Disclaimer: The statements, opinions and data contained in this publication are solely those of the individual authors and contributors and not of the publisher and the editor(s). The appearance of advertisements in the journal is not a warranty, endorsement, or approval of the products or services advertised or of their effectiveness, quality or safety. The publisher and the editor(s) disclaim responsibility for any injury to persons or property resulting from any ideas, methods, instructions or products referred to in the content or advertisements.
Subscription Rates: Subscriptions run for a full calendar year. Prices are given per year. Personal subscription:

Print or Online

CHF 1069.60

EUR 792.-

USD 1000.00

Print+Online combined CHF 1165.60

EUR 864.-

postage and handling (added to print and print+online)

CHF 52.40 Europe, CHF 78.- Overseas

EUR 39.20

USD 72.80

Institutional subscription:

Print or Online

Print+Online combined

CHF 2674.-

EUR 1980.-

CHF 2942.-

USD 2500.00

USD 2750.00

postage and handling (added to print and print+online)

CHF 65.60 Europe, CHF 97.60 Overseas

EUR 48.80

USD 91.20

Airmail surcharge: CHF 66.40 / USD 62.40
Back Volumes and Single Issues: Information on availability and prices of single print issues and print or electronic back volumes can be obtained from Customer Service at service@karger.ch.

Bibliographic Indices: This journal is regularly listed in bibliographic services, including Current Contents ${ }^{\circledR}$ and PubMed/MEDLINE.

Photocopying: This journal has been registered with the Copyright Clearance Center (CCC), as indicated by the code appearing on the first page of each article. For readers in the US, this code signals consent for copying of articles for personal or internal use, or for the personal or internal use of specific clients, provided that the stated fee is paid per copy directly to

Copyright Clearance Center Inc.

222 Rosewood Drive

Danvers, MA 01923 (USA)

A copy of the first page of the article must accompany payment. Consent does not extend to copying for general distribution, for promotion, for creating new works, or for resale. In these cases, specific written permission must be obtained from the copyright owner,

S. Karger AG, P.O. Box

CH-4009 Basel (Switzerland).
Subscription Orders:

Orders can be placed at agencies,

bookstores, directly with the Publisher

\section{S. Karger AG}

Medical and Scientific Publishers

P.O. Box

CH-4009 Basel

Switzerland

for courier services only:

Allschwilerstrasse 10

CH-4055 Basel)

t: +416130611 11

f: +41613061234

e: karger@karger.ch

w: www.karger.com or further Karger offices

or representatives:

Germany

S. Karger GmbH

Postfach

79095 Freiburg

Deutschland

(Hausadresse: Wilhelmstrasse 20A,

79098 Freiburg)

$\mathrm{t}: \quad+49761452070$

f: $\quad+497614520714$

e: information@karger.de

w: www.karger.de

Japan

Karger Japan, Inc.

Shiba Daimon Asahi Bldg. 2F

1-2-23 Shiba Daimon

Minato-ku

Tokyo 105-0012

Japan

t: +81364356242

f: +81364356244

e: publisher@karger.jp

w: www.karger.jp

Change of Address:

Both old and new address should be sent

to the subscription source.

USA

S. Karger Publishers, Inc.

26 West Avon Road

P.O. Box 529

Unionville, CT 06085

USA

Toll free: +18008285479

$\mathrm{t}: \quad+18606757834$

f: +18606757302

e: karger@snet.net

France

Librairie Médi-Sciences Sar

36, bd de Latour-Maubourg

75007 Paris

France

t: $+33(0) 145514258$

f: $+33(0) 145560780$

f: $+33(0) 145560780$

w: www.medi-sciences.fr

Gulf Council Countries, Iran,

Middle East, North Africa, Turkey

Trans Middle East International

Distribution Co. Ltd.

Kastrib

134 Queen Rania Al Abdullah Stree

Jordan Trade Center Bldg. 3rd Floor

P.O. Box 2376

Amman 11953

Jordan

t: +96265153467

f: +96265153472

e: info@kasha.cc

w: www.KaShaonline.com
South East Asia, China and Taiwan Karger Regional Office (Malaysia) CEO Suite Kuala Lumpur Quill 7, 27th Floor

Jalan Stesen Sentral 5

KL Sentral

Kuala Lumpur 50470

Malaysia

t. +60327766803

f: +60327766999

e: service@karger.cn; r.chew@karger.cn

\section{Karger China}

10th Floor, Twin Towers (East)

B12 Jianguomenwai Avenue

Beijing 100022

China

t: +861051235033

f: +861051235122

e: service@karger.cn; r.chew@karger.cn

w: www.karger.cn

India, Bangladesh, Sri Lanka

Medscience India

Plot No. 17, Yusuf Sarai Market

B.L. Glass Building, 2nd Floor

Sri Aurobindo Marg

New Delhi 110016

India

t: +911146029633

f: +911146029634

c: +919891052128

e: medsci.india@gmail.com

\section{KARGER}

Fax +4161306 1234

E-Mail karger@karger.ch

www.karger.com
(C) 2012 S. Karger AG, Basel

The Journal Home Page is available at:

www.karger.com $/ \mathrm{mmb}$ 


\section{Contents}

See the journal website for contents

KARGER Basel $\bullet$ Freiburg $\cdot$ Paris $\bullet$ London $\bullet$ New York $\cdot$ New Delhi $•$ Bangkok Beijing $\cdot$ Tokyo $\cdot$ Kuala Lumpur $\cdot$ Singapore $\bullet$ Sydney 


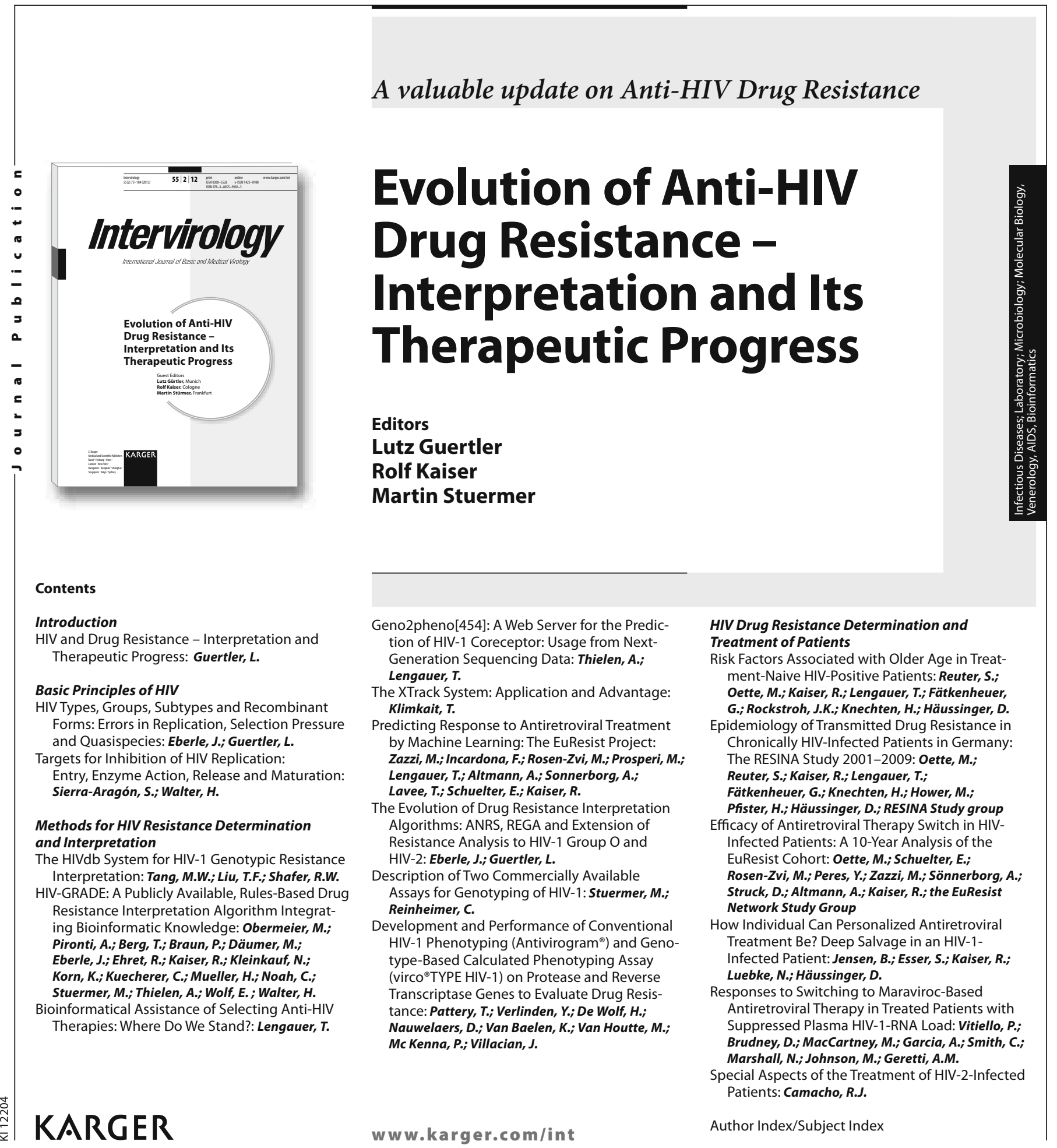

\section{$\rightarrow$ Please send: ___ copy/ies}

Postage and handling free with prepayment

E Editors: Guertler, L. (Munich); Kaiser, R. (Cologne); Stuermer, M. (Frankfurt)

112 p., 28 fig., 11 in color, 20 tab., soft cover , 2012 CHF 39.- / EUR 33.- / USD 46.00 Prices subject to change

EUR price for Germany, USD price for USA only

ISBN 978-3-8055-9902-3

e-ISBN 978-3-8055-9903-0

Special Topic Issue

Intervirology

Vol. 55, No. 2 (2012)

Included in subscription

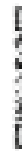

- Payment:

Please charge to my credit card

- $\square$ American Express $\square$ Diners

ᄂ $\square$ MasterCard

- Card No

๑

¿ Exp. date:

- CVV/CVC

( 3 digits in the signature field on the back of Visa and MasterCard)

$\square$ Check enclosed $\square$ Please bill me

Orders may be placed with any bookshop, subscription agency, directly with the publisher or through a Karger distributor.
Fax: +41 613061234

S. Karger AG, P.O. Box, CH-4009 Basel (Switzerland)

E-Mail orders@karger.ch, www.karger.com

Name/Address:

Date: 


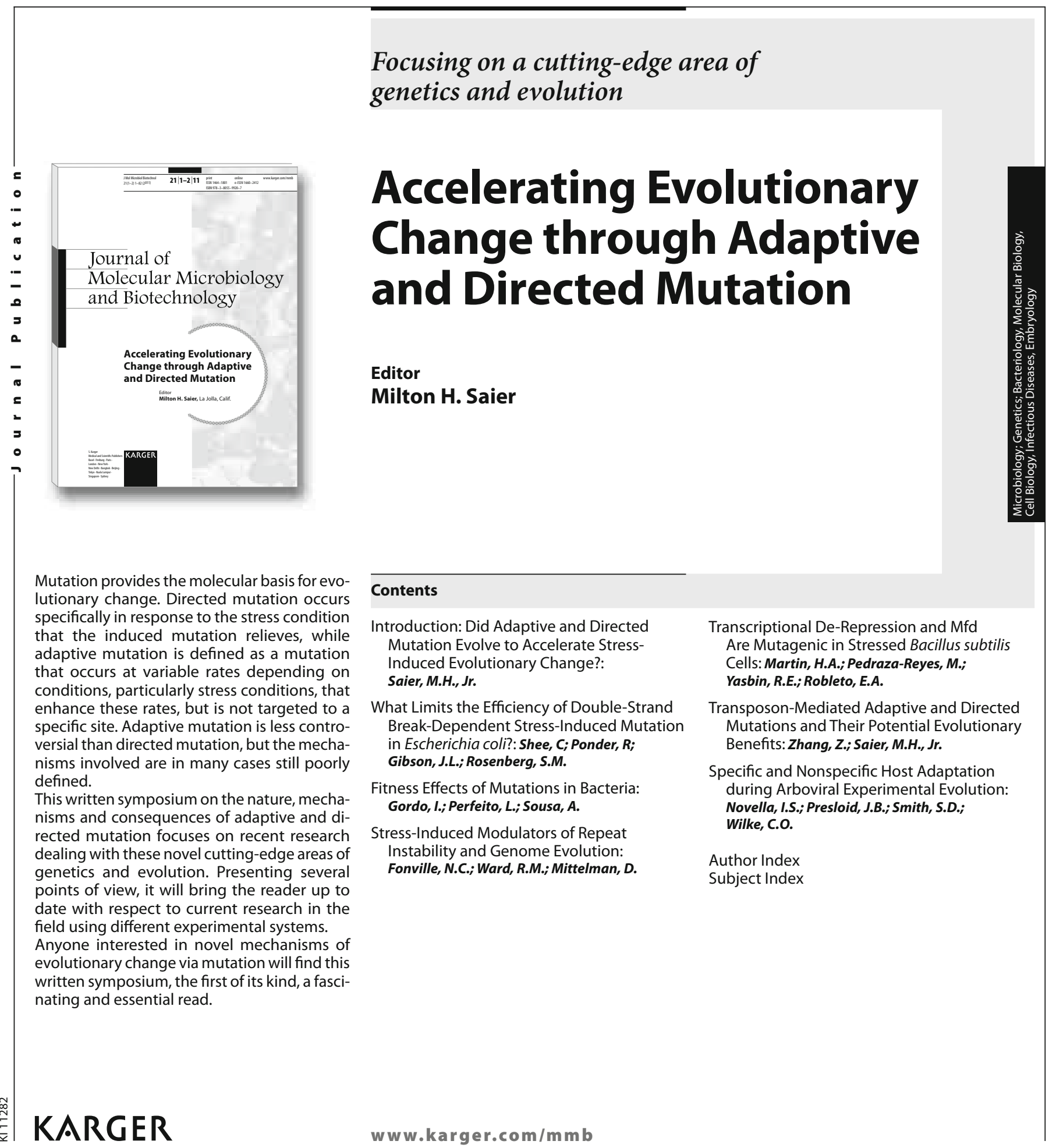

Accelerating Evolutionary Change through Adaptive and Directed Mutation Editor: Saier, M.H. (La Jolla, Calif.) 82 p., 23 fig., 4 in color, 7 tab., soft cover, 2012 CHF 39.- / EUR 33.- / USD 46.00 Prices subject to change EUR price for Germany, USD price for USA only ISBN 978-3-8055-9920-7

e-ISBN 978-3-8055-9921-4

Special Topic Issue:

Journal of Molecular Microbiology and Biotechnology

Vol. 21, No. 1-2 (2011)

Included in subscription

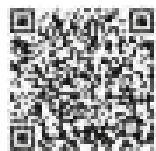

Please send: ___ copy/ies

Postage and handling free with prepayment

E Payment:

Please charge to my credit card

- $\square$ American Express $\square$ Diners

ᄂ $\square$ MasterCard $\square$ Visa

- Card No.:

๑

ర

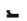

- CVV/CVC

( 3 digits in the signature field on the back of Visa and MasterCard)

$\square$ Check enclosed $\quad \square$ Please bill me

Orders may be placed with any bookshop, subscription agency, directly with the publisher or through a Karger distributo
Fax: +41613061234

S. Karger AG, P.O. Box, CH-4009 Basel (Switzerland)

E-Mail orders@karger.ch, www.karger.com

Name/Address: 


\section{With contributions by some of the most well-known specialists in tuberculosis research}

\section{Antituberculosis Chemotherapy}

\section{Antituberculosis Chemotherapy}

Edtrors
Peter R. Donald
Paul D. van Helde

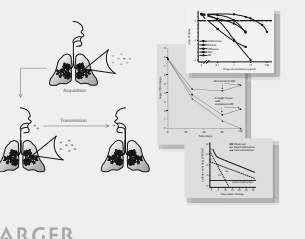

KARGER
Editors

Peter R. Donald

Paul D. van Helden
Tuberculosis (TB) remains one of the major infectious diseases of mankind although drugs for its treatment have been available for nearly 60 years. The standard short-course 6-month regimen used since about 1980 has helped to save millions of lives, but co-infection with HIV has had a devastating effect on the epidemic, and multidrug-resistant TB is a growing problem, particularly in communities with a high incidence of HIV. Following the declaration by the WHO in the early 1990s that TB was a 'global health emergency', interest in TB research and the development of new drugs has increased significantly.

This volume reviews anti-TB chemotherapy with the emphasis on the actions and pharmacology of existing drugs and the development and evaluation of new agents. A close look is taken at new research regarding our existing drugs by some of the best-known specialists in the field, and historical aspects of these agents are reviewed from a modern perspective. The prospects for the introduction of new drugs and different approaches of how to assess them in adults and in children are discussed in detail. Several papers address the problems associated with drug resistance, its spread and diagnosis.

Compiled by two editors from Cape Town, which has a particularly high incidence of TB and is a centre of tuberculosis research, this publication is an indispensable reference for anyone involved in the management of TB either as a researcher, clinician or administrator, and those working in drug development.

\section{Contents}

\section{Retrospectoscope}

History of Drug Discovery: Early Evaluation Studies and Lessons Learnt from Them: Ahmad, Z.; Makaya, N.H.; Grosset, J.

Tuberculosis Treatment Trials Past and Present: Old and New Challenges: Nunn, $\boldsymbol{N}$.

\section{Present Treatment}

The Rifamycins: Renewed Interest in an Old Drug Class: Burman, W.; Dooley, K.E.; Nuermberger, E.L.

Isoniazid Pharmacokinetics and Efficacy in Adults and Children: Donald, P.R.; Schaaf, H.S.

Recent Developments in the Study of Pyrazinamide: An Update: Mitchison, D.A.; Zhang, $\boldsymbol{Y}$.

Experience with Phase III Clinical Trials of Antituberculosis Drugs and Regimens: Conclusions and Lessons for the Future: Jindani, $\boldsymbol{A}$.

Fluoroquinolones in the Management of Tuberculosis: Singh, K.P.; Gillespie, S.H. Current Standard Treatment: Vernon, A.A. Tuberculosis Recurrence: Exogenous or Endogenous?: Williams, $\boldsymbol{M}$. et al.

Second-Line Antituberculosis Drugs: Current Knowledge, Recent Research Findings and Controversies: Schaaf, H.S. et al.

Acquisition, Transmission and Amplification of Drug-Resistant Tuberculosis: Müller, B. et al.

The Treatment of Tuberculosis in Children: Cruz, A.T.; Starke, J.R.

www.karger.com/prrer
The Future

Issues and Challenges in the Development of Novel Tuberculosis Drug Regimens: Erondu, N.; Ginsberg, A.

Drug Resistance in Mycobacterium tuberculosis: Molecular Mechanisms and Laboratory Susceptibility Testing: Böttger, E.C.

The Role of the Mouse Model in the Evaluation of New Antituberculosis Drugs: Nuermberger, E.L.

Current Issues in Tuberculosis Pharmacokinetics: Egelund, E.F.; Peloquin, C.A.

Pharmacological Considerations of Antitubercular Agents in Children: Goldman, J.L. et al.

Pharmacogenetics of Antituberculosis Drugs: Aarnoutse, $\boldsymbol{R}$.

Interactions between Antituberculosis and Antiretroviral Agents: Mcllleron, H.; Khoo, S.H.

Diabetes Mellitus and Tuberculosis Treatment: Ruslami, $R$; van Crevel, $\boldsymbol{R}$.

Early Bactericidal Activity of Antituberculosis Agents: Diacon, A.H.; Maritz, J.Z.; Donald, P.R.

Assessment of Whole-Blood Bactericidal Activity in the Evaluation of New Antituberculosis Drugs: Wallis, R.S.

Serial Sputum Colony Counting in Drug Development: Sloan, D.; Davies, $\boldsymbol{G}$.

The Evaluation of New Antituberculosis Drugs in Children: McNeeley, D.F. et al.

A New Era in Tuberculosis Treatment: What Does the Future Hold?: Duncan, $\boldsymbol{K}$.

Author Index / Subject Index

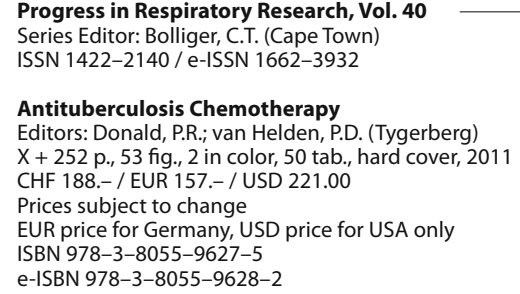

Please send: __ copy/ies

$\boldsymbol{\varepsilon}$

- Please charge to my credit card

- $\square$ American Express $\square$ Diners

ᄂ $\square$ MasterCard $\square$ Vis

$-$

๑

$\nabla$

CVV/CVC

( 3 digits in the signature field on the back of Visa and MasterCard)

$\square$ Check enclosed $\quad \square$ Please bill me

Orders may be placed with any bookshop, subscription agency, directly with the publisher or through a Karger distributor.
Fax: +41613061234

S. Karger AG, P.O. Box, CH-4009 Basel (Switzerland)

E-Mail orders@karger.ch,www.karger.com

Name/Address: 


\section{Journal of
Molecular Microbiology and Biotechnology}

Review

83 Phylogenetic Characterization of Transport Protein Superfamilies: Superiority of SuperfamilyTree Programs over Those Based on Multiple Alignments

Chen, J.S.; Reddy, V.; Chen, J.H.; Shlykov, M.A.; Zheng, W.H.; Cho, J.; Yen, M.R.; Saier, M.H., Jr. (La Jolla, Calif.)

Research Articles

97 Transcriptional Regulation of Mycobacterium tuberculosis PE/PPE Genes: A Molecular Switch to Virulence?

Mohareer, K. (Hyderabad); Tundup, S. (Athens, Ga.); Hasnain, S.E. (Hyderabad/New Delhi/Bangalore)

110 The FUS3/KSS1-Type MAP Kinase Gene FPK1 Is Involved in Hyphal Growth, Conidiation and Plant Infection of Fusarium proliferatum

Zhao, P.-B. (Liaocheng/Taian); Ren, A.-Z. (Liaocheng); Li, D.-C. (Taian)

120 Heterologous Expression of Manganese Peroxidase in Aspergillus niger and Its Effect on Phenanthrene Removal from Soil

Cortés-Espinosa, D.V.; Absalón, Á.E.; Sanchez, N.

(Tepetitla de Lardizabal); Loera, O.; Rodríguez-Vázquez, R.; Fernández, F.J. (Mexico)

130 Overexpression of the Key Virulence Proteases Bace16 and Bae16 in Bacillus nematocida B16 to Improve Its Nematocidal Activity

Niu, Q. (Kunming/Nanyang City); Tian, Y. (Kunming); Zhang, L. (Kunming/Nanyang City); Xu, X.; Niu, X. (Kunming); Xia, Z.; Lei, L. (Yuxi); Zhang, K.-Q.; Huang, X. (Kunming)
138 Evaluation of the Anti-Inflammatory Effect of Milk Fermented by a Strain of IL-10-Producing Lactococcus lactis Using a Murine Model of Crohn's Disease del Carmen, S.; de Moreno de LeBlanc, A.

(San Miguel de Tucumán); Perdigon, G. (San Miguel de Tucumán/ Tucumán); Bastos Pereira, V.; Miyoshi, A.; Azevedo, V. (Belo Horizonte); LeBlanc, J.G. (San Miguel de Tucumán)

147 Post-Transcriptional Regulation of the Alginate Biosynthetic Gene algD by the Gac/Rsm System in Azotobacter vinelandii

Manzo, J. (Puebla); Cocotl-Yañez, M. (Puebla/Cuernavaca); Tzontecomani, T.; Martínez, V.M. (Puebla); Bustillos, R.; Velásquez, C. (Puebla/Cuernavaca); Goiz, Y.; Solís, Y.; López, L.; Fuentes, L.E. (Puebla); Nuñez, C.; Segura, D.; Espín, G. (Cuernavaca); Castañeda, M. (Puebla)

160 Identification of Two Novel Reductases Involved in Equol Biosynthesis in Lactococcus Strain 20-92 Shimada, Y.; Takahashi, M.; Miyazawa, N.; Ohtani, T. (Tokushima); Abiru, Y.; Uchiyama, S. (Kanzaki); Hishigaki, H. (Tokushima)

173 Revealing the Latent Mobilization Capability of the Staphylococcal Bacteriocinogenic Plasmid pRJ9 Coutinho, B.G.; Coelho, M.L.V.; Ceotto, H.; de Freire Bastos, M.d.C. (Rio de Janeiro)

184 Evidence of Bacillus thuringiensis Intra-Serovar Diversity Revealed by Bacillus cereus Group-Specific Repetitive Extragenic Palindromic Sequence-Based PCR Genomic Fingerprinting

Sauka, D.H.; Basile, J.I.; Benintende, G. (Castelar)

Short Communication

191 Galleria mellonella as a Model for Studying Enterococcus faecium Host Persistence

Lebreton, F.; Le Bras, F.; Reffuveille, F.; Ladjouzi, R.; Giard, J.-C.; Leclercq, R.; Cattoir, V. (Caen) 